\title{
Current Dietary Lipids Recommendations: Pros and Cons
}

\section{Giraudo $\mathrm{S}^{* 1}$, Montero JC ${ }^{2}$, Kaufmann $\mathrm{P}^{3}$ and Grossman $\mathrm{B}^{1}$}

${ }^{1}$ Department of Foods and Nutrition, University of Georgia, Athens, Georgia

${ }^{2}$ Argentinean Association for the Study of Obesity (SAOTA), Buenos Aires, Argentina

${ }^{3}$ Uruguayan Society for the study of Obesity (SUPESO), Montevideo, Uruguay

*Corresponding author: Giraudo S, Department of Foods and Nutrition, University of Georgia, Athens, Georgia, E-mail: sgiraudo@uga.edu

Citation: Giraudo S, Montero JC, Kaufmann P, Grossman B (2016) Current Dietary Lipids

Recommendations: Pros and Cons. J Nutr Health Sci 3(4): 406. doi: 10.15744/2393-9060.3.406

Received Date: August 29, 2016 Accepted Date: November 28, 2016 Published Date: November 30, 2016

\begin{abstract}
The rise of chronic non-communicable diseases (CNCD), mainly cardiovascular disease, obesity and cancer, has been assumed to be a consequence of the increased intake of fatty foods, especially saturated fats and cholesterol. This assumption triggered a body of guidelines, recommending a decrease in fat and an increase in complex carbohydrates, with the use of some oils that are thought to be beneficial for health. However, these recommendations have not produced the expected results. Not only has CNCD not decreased, but instead it has increased markedly. In this paper we discuss the possible mechanisms for this unexpected outcome. Our main hypothesis is that an increase of the anabolic-inflammatory stimulation of the circulatory system and other tissues may contribute to CNCD. Hence, it would be prudent to rethink nutritional advice for at risk populations.
\end{abstract}

Keywords: Diet and chronic non-communicable diseases; Cardiovascular disease; Saturated fats and health; Obesity and fat; Diet and cancer; Cancer growth factors and insulin-resistance and diet

\section{Introduction: turning to carbs}

In the last hundred years, a major part of the developed world has shifted from a predominance of diseases caused by nutritional deficit to diseases caused by nutritional excess. Increasing income, improvement in the production and consumption of food, and an increase in the availability and intake of palatable processed food has triggered an epidemic of chronic disease.

Cardiovascular diseases and cancer are the two main causes of death in developed countries. In 2014, with over a total of 56 million deaths worldwide, $68 \%$ were caused by chronic non-communicable diseases (CNCD): $31 \%$ of them by cardiovascular diseases ( 17.5 million), $14.6 \%$ by cancer ( 8.2 million), $2.7 \%$ by diabetes ( 1.5 million) and $7.1 \%$ by respiratory diseases ( 4 million). These four groups of diseases account for $82 \%$ of all non-communicable diseases [1].

Taking into account that in the last 10,000 years the spontaneous mutation of nuclear DNA was calculated to be only of $0.0005 \%$, it can be concluded that the increase in the rate of degenerative illness (such as atherosclerosis, tumors or fatty liver) is certainly not of a genetic origin but mainly attributable to environmental changes, in particular to eating habits $[2,3]$.

The main dietary recommendations for populations have been aimed at controlling cardiovascular diseases and obesity. These suggestions were inspired by the hypotheses that cholesterol and saturated fats were responsible for injuring arterial walls, and also that obesity was caused by an energetic imbalance due to an excess of dietary fat and inadequate physical activity [4]. These dietary recommendations encouraged a decrease in the consumption of animal products (saturated fats, cholesterol and total fats) in spite of the fact that more than $50 \%$ of the calories ingested by many populations usually come from sources other than animal products [5-7].

These official guidelines of the last 20 years have encouraged food producers and the pharmaceutical industry to develop products aimed at decreasing both dietary fat and cholesterol with the hope that this would in turn contribute to decreasing the levels of these substances in circulating blood. As a result of these recommendations by the USDA, the American Heart Association (AHA) and the American Diabetes Association (ADA), the intake of saturated fat has decreased from 13.5 to $10.6 \%$ of daily calories for males and from $13.0 \%$ to $11.0 \%$ for women, while the consumption of carbohydrates has increased from $42.4 \%$ to $49.0 \%$ for males and $45.4 \%$ to $51.6 \%$ for women [8]. From 1970 to 2008 , calorie intake has increased 616 Kcal due in large part to added fats (+213 Kcal) and flour and grain products (+193 Kcal) (Table 1). 


\begin{tabular}{|c|c|c|c|c|}
\hline $\begin{array}{c}\text { FOOD INTAKE CHANGES BETWEEN 1970 AND 2008 } \\
\text { (expressed in calories) }\end{array}$ \\
\hline Year & 1970 & 1990 & $\mathbf{2 0 0 8}$ & 1970 vs 2008 \\
\hline Components & \multicolumn{4}{c|}{ Calories } \\
\hline Dairy & 155 & 260 & 257 & $+102(+66 \%)$ \\
\hline Fruits & 71 & 85 & 87 & $+16(+23)$ \\
\hline Vegetables & 125 & 126 & 122 & $-3(-2 \%)$ \\
\hline Meat - eggs and nuts & 463 & 453 & 482 & $+19(+4 \%)$ \\
\hline Flour and grain products & 432 & 573 & 625 & $+193(+45 \%)$ \\
\hline Caloric sweeteners & 402 & 446 & 459 & $+57(+14 \%)$ \\
\hline Added fats and oils & 403 & 446 & 616 & $+213(+53 \%)$ \\
\hline Other dairy fats & 6 & 15 & 25 & $+19(+417 \%)$ \\
\hline TOTAL & 2057 & 2404 & 2673 & $+616(+30 \%)$ \\
\hline
\end{tabular}

Table 1: Food Intake Changes Between 1970 AND 2008 (expressed in calories) [9]

\section{Food fat and obesity}

Data from 10 cohort studies and the meta-analysis of 33 randomized and controlled trials (73,589 people) in developed countries showed that low fat diets were associated with a slightly lower body weight [10]. However, the reported difference of $1.6 \mathrm{~kg}$ (on average), although statistically significant, does not correlate with the increase in BMI (from 25 to 30) [10].

In China, an increase of $10 \%$ in fat calories showed a non-significant BMI increase of only 0.1 in adolescents and of 0.003 in adults. In South Africa, a rather high incidence of overweight (>55\%) is related to a low fat consumption of $22 \%$ [11].

On the other hand, it is important to bear in mind that in the US, a decrease of fat consumption from $37 \%$ to $33 \%$ in men and from $36 \%$ to $33 \%$ in women has resulted in an increase of overweight and obesity in the past 40 years [12,13]. Obesity increased from $12.6 \%$ in 1991 to $33.9 \%$ in 2015 while overweight increased from $36.7 \%$ in 1995 to $66.9 \%$ in 2010 as reported by the World Health Organization [14]. In Argentina, the prevalence of obesity has increased from $14.6 \%$ to $18.0 \%$ from 2005 to 2009 and overweight from $34.4 \%$ to $35.4 \%$ [15].

\section{Calories: mechanism, not cause}

Obesity is a result of energy imbalance which may be influenced by many elements, including non-caloric factors that might be influencing body composition. These may include 1) the feeding cycle (e.g. in animal experimentation, a reversed light cycle produces a greater increase in weight with the same energy consumption); 2) metabolic regulation (e.g. an impairment of the adipose insulin receptor protects against the weight increase observed in controls); 3) changes in the muscular efficiency after weight loss; 4) the influence of non-energetic nutrients ( e.g. deficits of calcium or vitamin D) which decrease the loss of weight produced by low caloric diets; 5) biphenyls; and 6) intestinal microflora, whose composition is related to the level of adiposity [16-26].

\section{Food sources and nutrients}

Although neither the Food and Agriculture Organization (FAO) nor the World Health Organization (WHO) consider dietary fat as particularly causative factor in obesity or atherosclerosis; the Institute of Medicine-National Academy of Science (IOM-NAS), American Heart Association (AHA) and Academy of Nutrition and Dietetics (AND) recommend a maximum of 35\% for dietary fat intake and maximum of $35 \%$ protein, while allowing up to 50 to $65 \%$ of carbohydrates. Thus for a diet of $2000 \mathrm{Kcal}$, about 300 g of glucose $(\sim 60 \%)$ would be recommended [5]. An intake of $300 \mathrm{~g}$ of glucose appears to be too much if we consider that: 1$)$ the human storage capacity is about $320 \mathrm{~g}$ (see table 2), 2) the daily estimated requirement is about $60-65 \mathrm{~g}$ of glucose 3 ) the difficulty of eating this amount of glucose if one only consumes natural foods and beverages [27] (Table 2).

\begin{tabular}{|c|c|c|c|}
\hline \multicolumn{4}{|c|}{$\begin{array}{c}\text { CARBOHYDRATES IN 70 KG ADULTS IN POST-ABSORTIVE STATE } \\
\text { (adapted from reference) [28] }\end{array}$} \\
\hline Tissue mass & $\begin{array}{c}\text { Liver } \\
(1.800 \mathrm{~kg})\end{array}$ & $\begin{array}{c}\text { Muscle } \\
(35 \mathrm{~kg})\end{array}$ & $\begin{array}{c}\text { Extra-cellular fluids } \\
\text { (every 10 liters) }\end{array}$ \\
\hline $\begin{array}{c}\text { Glycogen and glucose } \\
\text { and tissue concentration }\end{array}$ & $\begin{array}{c}72 \mathrm{~g} \\
(4 \%)\end{array}$ & $\begin{array}{c}245 \mathrm{~g} \\
(0.7 \%)\end{array}$ & $\begin{array}{c}10 \mathrm{~g} \\
(0.1 \%)\end{array}$ \\
\hline
\end{tabular}

Table 2: Carbohydrates in $70 \mathrm{Kg}$ Adults in Post-Absorptive State (adapted from reference)

It should also be noted that concentrated carbohydrates, often associated with fats and present in processed foods, are a main source of solid fats and added sugar (SoFAS) in the diet. The USDA Guidelines for 2015 suggest that intake of SoFAS and products 
obtained by refining grains typically exceed the recommended levels [29]. The main five sources of SoFAS for the population over 2 years of age are shown in table 3 :

\begin{tabular}{|c|c|c|c|}
\hline SOLID FATS (SoFAS) & $\begin{array}{c}\text { \% CONTRIBUTION } \\
\text { IN FOODS }\end{array}$ & $\begin{array}{c}\text { ADDED } \\
\text { SUGARS (AS) }\end{array}$ & $\begin{array}{c}\text { \% CONTRIBUTION } \\
\text { IN FOODS }\end{array}$ \\
\hline Rice, pasta, grain dishes & 5 & $\begin{array}{c}\text { Soft drinks, } \\
\text { energy drinks }\end{array}$ & 28 \\
\hline Pizza & 6 & Grains & 8 \\
\hline Dairy & 13 & Fruit drinks & 11 \\
\hline $\begin{array}{c}\text { Burgers, sandwiches, } \\
\text { meat, poultry, seafood } \\
\text { dishes }\end{array}$ & 23 & Dairy desserts & 4 \\
\hline Vegetables & 7 & Candy & 31 \\
\hline TOTAL & 54 & & 82 \\
\hline
\end{tabular}

Table 3: Five sources of SoFAS for the population over 2 years of age [29]

Solid fats are found in coconut oil, palm oil, butter, tallow, bacon, shortening and solid margarine (these last two contain partially hydrogenated oil which contains trans-fatty-acids). In liquid form, saturated fat is also found in olive oil, soy oil, corn oil and sunflower oil [30] (Table 4).

\begin{tabular}{|c|c|c|c|c|}
\hline \% OF FATTY ACIDS & SOY OIL & OLIVE OIL & CORN OIL & SUNFLOWER OIL \\
\hline Saturated & 14.0 & 14.0 & 17.0 & 12 \\
\hline $18: 1(\mathrm{n}-9)$ & 25.0 & 72.0 & 30.0 & 33 \\
\hline $18: 2(\mathrm{n}-6)$ & 52.0 & 11.0 & 50.0 & 52 \\
\hline $18: 3(\mathrm{n}-3)$ & 7.0 & 1.0 & 2.0 & Trace \\
\hline $\mathrm{n}-6 / \mathrm{n}-3$ ratio & $7.42 / 1$ & $11 / 1$ & $25 / 1$ & $52 / 1$ \\
\hline
\end{tabular}

Table 4: Saturated fat found in olive oil, soy oil, corn oil and sunflower oil [30]

\section{Fatty acids: are they toxic or beneficial?}

An association between high-fat diets and impaired insulin action has been observed in numerous in vivo and in vitro studies. Studies suggest that an intracellular excess of fatty acids may result in a decrease in insulin sensitivity affecting the beta cells of the pancreas $[31,32]$. This decrease in insulin sensitivity results in an increase in the release of fatty acids from adipose tissue, which are then deposited in other tissues, preventing the oxidation of glucose. As a result of this glucose sparing, the circulating level of glucose increases, producing glucotoxicity [32].

Hence, excess fatty acids may induce not only insulin resistance, but also glucotoxicity. In contrast, energy restriction improves insulin sensitivity, reduces fasting glucose, and insulin concentration. Thus, energetic restriction does not cause gluco- or lipotoxicity, on the contrary, it rather corrects it. In addition, restriction does not promote morbidity or mortality, and instead, it tends to extend life [33].

These beneficial actions of energy restriction may be attributed to an increase of transcription factor FOXO1, which is normally restrained by insulin, and to a lesser activity of growth factor1 (IGF-1) and of mTOR (mammalian target of rapamycin), both of which are stimulated by insulin $[34,35]$.

\section{Dietary fats and their cardiometabolic associations}

The respiratory quotient produced by a Western diet is approximately $0.80-0.85$, which is equivalent to the oxidation of approximately equal amounts of glucose and fatty acids. Indeed this oxidation profile occurs with formulations of calories from $41 \%$ fat, $45 \%$ carbohydrate and $14 \%$ protein. A similar oxidation level is observed with whole milk which has a profile of $53 \%$ fat, $41 \%$ carbohydrate and $8 \%$ protein profile [36]. In contrast, most of foodstuff ingested by indigenous populations is characterized by low carbohydrate, and contains a high percent of fat and protein. For example, Massai warriors whose diet is mainly meat, milk and blood and is estimated to include $60 \%$ of fat calories (33\% saturated fat), exhibit no cardiovascular disease, despite their low level of physical activity [37-40]. Inuit Eskimos have an intake of more than 70\% of fat calories, but chronic diseases are uncommon among them [41]. Tokelau aborigines, native of a New Zealand territory island, obtain 53\% of their daily energy intake from coconut oil (which is $90 \%$ saturated fat), $13 \%$ protein and $34 \%$ carbohydrate. This notwithstanding, the prevalence of cardiovascular diseases is rather low in this population [42]. The Mediterranean diet, which contains $45 \%$ of fat, is highly recommended for diabetic patients because of its favorable effects on blood glucose and the prevention of cardiovascular diseases [43]. The Atkins diet, in which more than 50\% of the energy comes from fat-mainly saturated ones- shows a better metabolic profile than the AHA or the very low fat Ornish diet [44]. 
It is also important to bear in mind that meta-analysis of diet composition proves no clear relationship between saturated fat intake and cardiovascular disease [45]. In addition, coronary disease risk cannot be predicted by reference to the level of saturated fat in meals [46].

However, eleven prospective studies of American and European cohorts have shown that replacing saturated fats by carbohydrates increased coronary risk [47]. In the famous "Study of the Seven Countries" by Ancel Keyes, several of the populations analyzed did not show a correlation between saturated fat intake and coronary mortality [48]. Further, the male populations of Finland, USA, Zutphen (Netherlands) and Crete differ substantially in coronary mortality in spite of the fact that they have a similar daily fat intake of approximately 40\% [49]. In contrast, as seen in Figures 1 and 2, seven European countries with lower intakes of saturated fat (under 7.5\%) had the greatest rates of mortality due to heart disease, whereas seven countries with the highest intakes (around 15\%) had the lowest rates (Figures 1 and 2) [49].

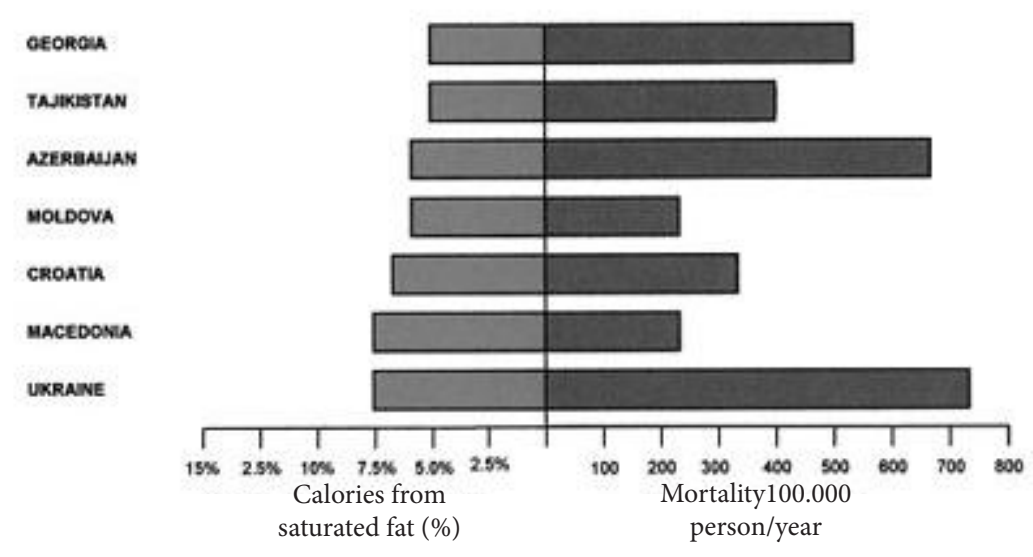

Figure 1: Mortality caused by cardiovascular decease and low intake $(\leq 7.5 \%)$ of saturated fat

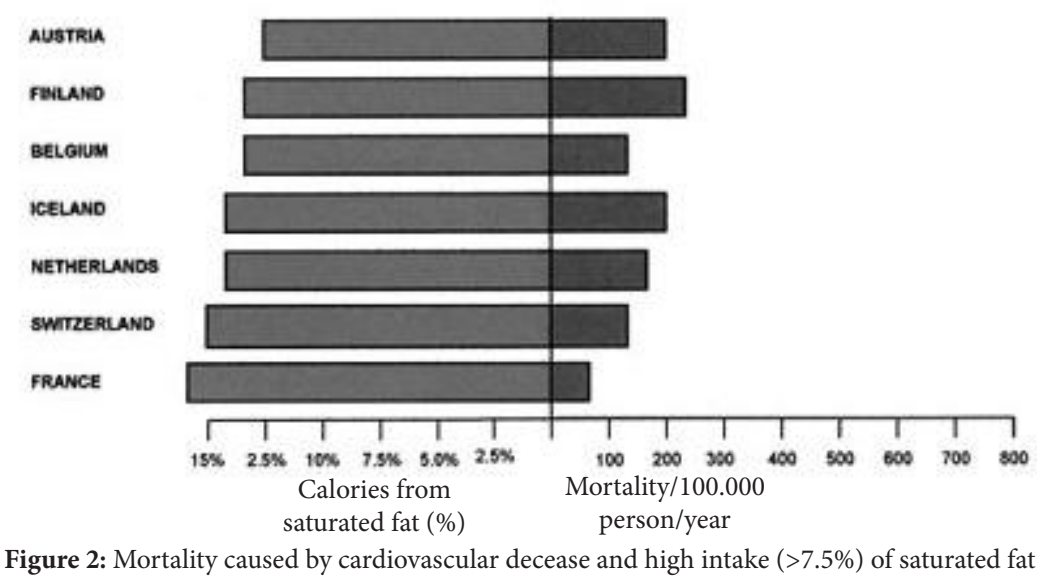

In addition, a review of 146 prospective papers and 43 randomized clinical reports shows that cardiovascular diseases were not attributable to fat intake [50,51]. In a 2010 paper, "Fat and Fatty Acids in Human Nutrition", FAO-OMS acknowledge that the evidence relating saturated fat intake to metabolic syndrome and cancer is insufficient [52]. This conclusion is supported by the fact that about $50 \%$ of the fatty acids in cell membranes are saturated and their proportions are almost indifferent to any changes in diet. This phenomenon also occurs with mono-unsaturated fats [53]. Conversely, essential fatty acids in the membrane are quickly influenced by the quality of fats ingested [53].

\section{Metabolic syndrome or substrate excess?}

The daily fluctuations in blood insulin levels together with changes in insulin receptor sensitivity suggest that cellular glucose consumption is regulated, especially for the tissues which are glucose dependent [54]. The variables regulating the entrance of glucose to the cell are glucose transporter 4 (GLUT4), the accumulation of certain lipids, and the effect of the ribosomal protein S6K (activated by mTOR), among others [55-58]. The fluctuations of the hormonal and tissue metabolites of this system prevent elevated glucose entry to the tissues and results in excessive postprandial hyperglycemia, thereby protecting those tissues which do not regulate glucose entry [59].

Non-enzymatic glycosylation of tissue proteins, imperfect electron transport in the respiratory chain and increase in the 
hexosamine pathway lead to an excessive production of reactive oxygen species (ROS), which are a direct cause of the glucotoxic injury [60-63]. ROS, as sensors of oxidative stress contribute to the impairment of insulin-mediated glucose uptake thereby preventing local glucotoxicity at the expense of raising glycemia and insulinemia $[64,65]$. This increased glycemia and insulinemia in turn leads to greater glucose utilization by: a) increasing glucose oxidation by reducing the adipose tissue release of fatty acids and b) stimulating glucose transformation in fat and cholesterol via the "de novo" synthesis of fatty acids and cholesterol [66-71]. Hyperglycemia and hypertriglyceridemia may result from the above process which may be considered as signs of calorie excess, due to cellular impairment of glucose and triglyceride utilization [72].

Due to the fact that an abnormal increase of insulin resistance is found in almost $30 \%$ of normal weight individuals the progressive increase of weight during aging could in part be attributable to excess circulating nutrients and to hyperinsulinism (characteristics of metabolic syndrome), due to the insulin resistance [73]. Thus, excess body weight or hyperphagia may be the result, rather than the cause of the hyperinsulinemia and excess circulating nutrients.

In support of this hypothesis, it has been shown that after experimental injury of the hypothalamus, there is an increase of insulinemia that precedes the hyperphagia and obesity Ransom [74]. Hyperinsulinemia and a greater trophism of intestinal mucous preceded the development of obesity after ventromedial hypothalamus injury [75]. Likewise, the deletion of the insulin gen 2 (Ins 2 -/-) in mice who continue to exhibit some insulin activity due to intact activity of gen insulin 1(Ins 1 -/+), showed no hyperinsulinemia, obesity or metabolic syndrome when exposed to obesogenic diet. It was suggested that their fat cells were reprogrammed to waste the excess nutrients as heat, $\mathrm{CO}_{2}$ and water [76].

\section{Does less calories mask less carbs?}

In 1464, Luigi Cornaro proposed the benefits of restricted eating in "Discourses on the Temperate Life" [77]. Nematodes, insects and mammals respond to dietary restriction by altering their glucose homeostasis and insulin signaling. It has been suggested, that limiting calories can modulate inflammation, insulin sensitivity, cellular cycle, tissue proliferation and apoptosis [78].

By increasing bioavailability of IGF-1 insulin mediates the anabolism and cellular proliferation associated with overeating. This increase in IGF-1 in turn coincides with the over- expression of the insulin receptor and its increased sensitivity in malignant cells $[79,80]$.

$\mathrm{m}$-TOR, a protein kinase, is an integrator of metabolic (ATP/AMP, AMPK), nutritional (glucose, amino acids, especially leucine) and hormonal signals (insulin and IGF-1) all related to cell proliferation and insulin resistance [81]. AMP-activated protein kinase (AMPK) promotes activity of Forkhead box protein 01 (FOXO1) which is inhibited by insulin and which has action against stress, tumors and inflammation. mTOR activation releases ribosomal protein $\mathrm{S} 6 \mathrm{~K} 1$ which increases insulin resistance and regulates cell proliferation and apoptosis [82-88].

The Akt-mTOR pathway remains sensitive to insulin in type 2 diabetics, obese non-diabetics and insulin-resistant obese nondiabetics and is involved in atherogenesis by increasing collagen, cellularity and pro-inflammatory cytokines in vascular tissues [89-91].

Reduction of circulating insulin levels caused by food restriction contributes to decreasing m-TOR activity which may improve some complications of diabetes, such as nephropathy, retinopathy, atherosclerosis and coronary diseases [92-95] (Figure 3).

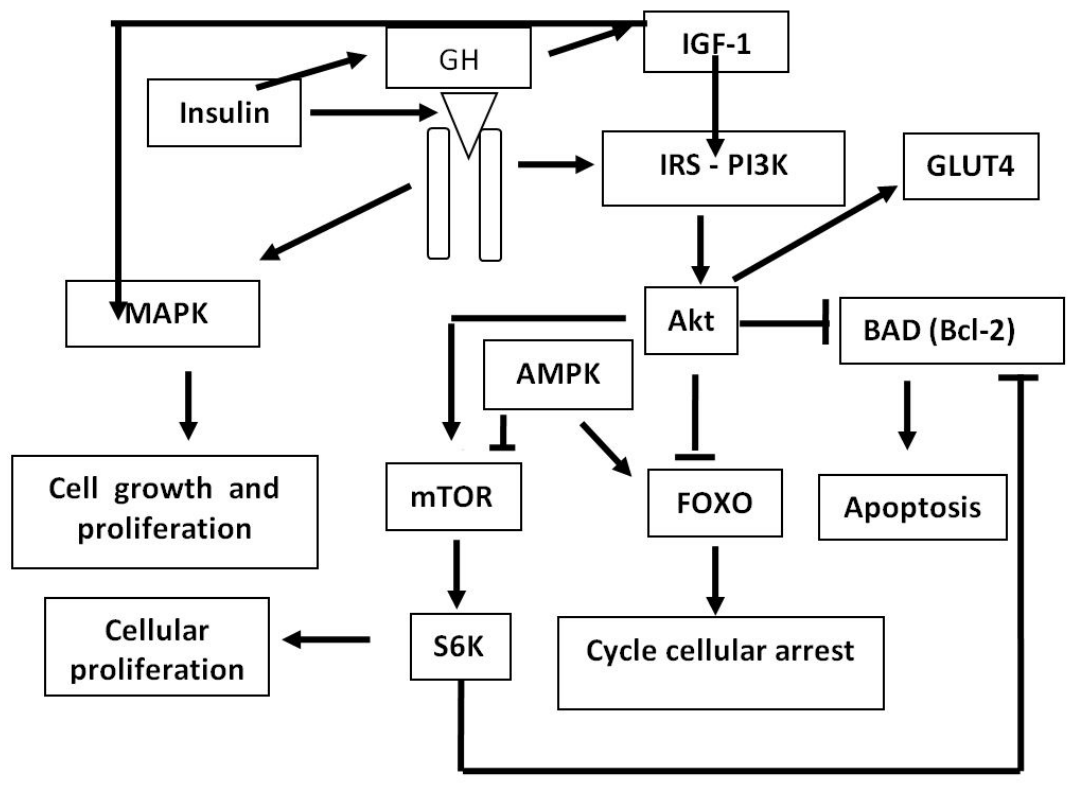

Figure 3: Main signalization ways activated by insulin receptor and growth factors (taken from references modified) [79-82] 
AMPK: (AMP activated protein kinase): indicates energy associated with ATP/AMP level $B A D$ : (Bcl-2-associated death promoter): Protein of apoptotic family such as a Bcl-2

FOXO: (transcription factor forkhead box). Has anti-stress, anti-proliferative, anti-inflammatory and hyperglycemic properties

GH: (Growth Hormone): over-regulate IGF-1 IGF-1: activate PI3K and MAPK

$A K t$ : Serine-threonine protein kinase or protein kinase $\mathrm{B}$

S6K: ribosomal S6 protein kinase: is required for protein synthesis and promotes insulin-resistance

$m$-TOR: active S6K, sensor of amino-acids and energy

IGF-1: Insulin-like growth factor 1

IRS - PI3K: Insulin activation of phosphatidylinositol 3-kinase

GLUT4: Glucose transporter type 4

MAPK: Mitogen-activated protein kinases

An apparent paradox exists such that the reduction of insulin signaling via IGF-1 increases life expectancy. But resistance to insulin, which also reduces insulin signaling/IGF-1, leads to decreased life expectancy and to diabetes. In the first condition, the low insulinemia produces low mTOR activation, while in the second case, insulin resistance, mTOR activation is enhanced [96,97].

\section{Carbs and liver}

The Western diet is rich in processed sugars (such as fructose) and fat, has been associated with metabolic impairment in nonhuman primates and hepatic steatosis in obese rats [98,99]. Excessive intake of fructose has been linked with weight gain, diabetes, inflammation, hyperuricemia, hypertension, vascular diseases and fatty liver. Even when consumed in low amounts and for a short period of time ( 3 weeks), the consumption of soft drinks leads to a reduction of the size of LDL, changes in glycemia and an increase in C-reactive protein [100]. These changes help explain the association between fructose and vascular diseases and/or metabolic syndrome. Hepatic metabolism of fructose causes fat accumulation and inflammation in the liver. Non-alcoholic fatty liver disease may result in steatohepatitis fibrosis (20-50\%), cirrhosis (20\%) or hepatocellular carcinoma (1-5\%) [101-104].

High fructose corn syrup became a market product in 1970 and between 1970 to 2000, its consumption increased from $0.5 \mathrm{lb}$ per capita in 1970 to $55.3 \mathrm{lb}$ per capita in 1993 [105]. Fructose consumption increased from $37 \mathrm{~g} /$ day in 1977-78 to 55 g/day in 1988-94 (NHANES III) [106]. In US, the average consumption of added sugars and sweeteners in 2010 was $19 \%$ higher than in 1970 [107].

High fructose corn syrup is a mixture of different proportions of glucose and fructose, but it typically contains 55\% of fructose. It has replaced sucrose as sweetener in most soft drinks, candies, canned fruits, ice cream, cookies, etc [108]. After its duodenojejunal absorption, fructose arrives via portal vein at the liver, where it is extracted in high amounts as its entrance transporter is not regulated. In addition, the fructose transporter is not present at either the brain or the pancreas, thus fructose does not trigger central satiety signals or insulin secretion in proportion to the amount ingested [109-112]. When fructose enters the liver it is phosphorylated and transformed in fructose-1-phosphate (F1P) [113]. Chronic consumption of fructose promotes a quick depletion of ATP [114]. F1P is a precursor of trioses which enter the "de novo" synthesis of triglycerides and cholesterol [113].

An acute cellular deficit of ATP activates the adenosin-monophosphate-deaminase-1, which in turn, increases the synthesis of uric acid thereby increasing the risk of gout and hypertension (due to the uric acid inhibition of endothelial synthetase of nitric oxide) [115-119]. These disorders have been observed in adolescents consuming high amounts of soft drinks. Hypertension combined with hyperuricemia may promote vascular damage, even when treated with antihypertensive drugs [120].

In mice, fructose increases the translocation of intestinal bacterial toxins. This translocation causes an increase of TNF alpha, resulting in hepatic steatosis [121].

If the fructose stream is substantial, and/or if glycogen deposits are full, the acetyl CoA produced by fructose can be a substrate for "de novo" lipogenesis, which can increase up to 10 -fold [122,123]. Fatty acids can be exported as low density lipoproteins, resulting in hypertriglyceridemia (see table 5) and/or can be deposited as fat in the hepatocyte [124,125].

The effect of carbohydrates on responding elements such as ChREBP, is higher for fructose than for other sugars, as isocaloric replacement of glucose by fructose increases intrahepatic fat by $38 \%$ in 8 days [126-129] (Table 5).

After 8 weeks of ingesting $25 \%$ of calories from soft drinks containing fructose, subjects showed a greater weight gain $(+1.4$ $\mathrm{kg}$ ) and a significant increase of intra-abdominal fat fructose as compared to glucose ingestion [124]. Thus, in hypercaloric conditions, fructose may produce "de novo" lipogenesis, hypertriglyceridemia, liver steatosis, insulin-resistance and increased ROS production, with risk of hepatocellular damage [129]. Taking into account its lipogenic potential, its inflammatory action, and its triggering of insulin-resistance, fructose may be considered as an etiopathogenic factor of NAFLD and cardiovascular risks, such as dylipidemia, hyperuricemia, hypertension and obesity. 


\begin{tabular}{|c|c|c|}
\hline \multicolumn{3}{|c|}{$\begin{array}{l}\text { IMPACT OF FIVE DIFFERENT CARBOHYDRATES ON CIRCULATING } \\
\text { TRIGLYCERIDS AFTER A MEAL CONTAINING } 40 \text { g. OF FAT }{ }^{*}\end{array}$} \\
\hline Treatment & $\begin{array}{l}\text { Lipidemia post-prandial } \\
\text { total }\left(\mathrm{mmol.} \mathrm{L}^{-1} .7 \mathrm{~h}^{-1}\right)\end{array}$ & $\begin{array}{l}\text { Maximal increment of post- } \\
\text { prandial triglycerides }(\mathrm{mmol} / \mathrm{L})\end{array}$ \\
\hline $50 \mathrm{~g}$ fructose & $4.23 \pm 2.10^{\mathrm{a}}$ & $1.06 \pm 0.52^{\mathrm{a}}$ \\
\hline $100 \mathrm{~g}$ sucrose & $3.77 \pm 1.90^{\mathrm{a}}$ & $0.96 \pm 0.46^{\mathrm{a}}$ \\
\hline 50 g glucose (iv) & $3.55 \pm 1.68^{b}$ & $0.86 \pm 0.44^{\mathrm{a}}$ \\
\hline $50 \mathrm{~g}$ sucrose & $2.75 \pm 1.33^{\mathrm{b}}$ & $0.71 \pm 0.32^{c}$ \\
\hline Meal & $2.42 \pm 1.24^{\mathrm{b}}$ & $0.63 \pm 0.33^{c}$ \\
\hline 50 g glucose (oral) & $2.11 \pm 1.23^{c}$ & $0.57 \pm 0.27^{c}$ \\
\hline
\end{tabular}

${ }^{*}$ Media \pm SD. $\mathrm{n}=21$ ( 9 males, 12 females)

Table 5: Impact of Five Different Carbohydrates on Circulating Triglycerids [124]

\section{Conclusions}

In the last 100 years, in the developing world, diseases due to nutritional deficit have been replaced by diseases due to nutritional excess. These changes parallel an increase in the production and consumption of highly processed foods. As a consequence, health authorities have promoted a diet to decrease cardiovascular disease and obesity, namely a diet consisting of low-fat foods in conjunction with high levels of "healthy" carbohydrates (45-65\% of calories), such as whole grains, fruits and vegetables.

Despite these recommendations, there has been limited success with this strategy. While deaths attributable to heart disease have declined in the last 20 years, obesity rates continue to climb. Of course, a sedentary lifestyle is a contributor to chronic disease. Genetics also plays a role, but most likely is not an immediate cause of this increase as our genetic pool cannot change in such a relatively short amount of time.

Perhaps it is time to re-visit the dietary prescriptions advanced by government organizations and health associations. Indeed, studies have indicated that dietary macronutrient composition can vary widely with no effect on body weight, as long as energy intake is balanced by output [130]. Due to the relatively satiating effects of protein and fat, it may be prudent to promote higher intakes of these macronutrients and lower intakes of carbohydrates.

\section{References}

1. World Health Organization (WHO) Global Health Observatory (GHO) data, USA.

2. Eaton SB, Konner M (1985) Paleolithic nutrition. A consideration of its nature and current implications. N Engl J Med 312: 283-9.

3. Jeffery RW, Harnack LJ (2007) Evidence implicating eating as a primary driver for the obesity epidemic. Diabetes 56: 2673-6.

4. Huttunen JK, Manninen V, Mänttäri M, Koskinen P, Romo M, et al. (1991) The Helsinki Heart Study: central findings and clinical implications. Ann Med 23: 155-9.

5. Dietary Reference Intakes for Energy Carbohydrate Fiber Fat Fatty Acids Cholesterol Protein and-Amino-Acids, National Academic Press, Washington, D.C., USA.

6. Food and Agriculture Organization of the United Nations (FAOSTAT) FAO Statistics Division 2010, Food Balance Sheets, Rome, Italy.

7. Kushi LH, Byers T, Doyle C, Bandera EV, McCullough M, et al. (2006) American Cancer Society Guidelines on Nutrition and Physical Activity for cancer prevention: reducing the risk of cancer with healthy food choices and physical activity. CA Cancer J Clin 56: 254-81.

8. U.S. Departments of Agriculture (USDA) Report of the Dietary Guidelines Advisory Committee on the Dietary Guidelines for Americans, 2010, USA.

9. United States Department of Agriculture (2016) Economic Research Service (ERS) Food Availability (Per Capita) Data System, USA.

10. Hooper L, Abdelhamid A, Moore HJ, Douthwaite W, Skeaff CM, et al. (2012) Effect of reducing total fat intake on body weight: systematic review and metaanalysis of randomized controlled trials and cohort studies. BMJ 345: e7666.

11. Willett WC (1998) Is dietary fat a major determinant of body fat? Am J Clin Nutr 67: 556S-62S.

12. Heini AF, Weinsier RL (1997) Divergent trends in obesity and fat intake patterns: the American paradox. Am J Med 102: $259-64$.

13. Hite AH, Feinman RD, Guzman GE, Satin M, Schoenfeld PA, et al. (2010) In the face of contradictory evidence: Report of the Dietary Guidelines for Americans Committee. Nutrition 26: 915-24.

14. World Health Organization (WHO) Global Database on Body Mass Index an interactive surveillance tool for monitoring nutrition transition, USA.

15. Ministerio de Salud (2009) Second National Risk Factors Survey (ENFR) [Segunda Encuesta Nacional Factores de Riesgo (ENFR)], Argentina.

16. Asterholm IW, Scherer PE (2012) Metabolic jet lag when the fat clock is out of sync. Nat Med 18: 1738-40.

17. Blüher M, Michael MD, Peroni OD, Ueki K, Carter N, et al. (2002) Adipose tissue selective insulin receptor knockout protects against obesity and obesityrelated glucose intolerance. Dev Cell 3: 25-38.

18. Chen HC, Jensen DR, Myers HM, Eckel RH, Farese RV Jr (2003) Obesity resistance and enhanced glucose metabolism in mice transplanted with white adipose tissue lacking acyl CoA:diacylglycerol acyltransferase 1. J Clin Invest 111: 1715-22.

19. Silva JE (2003) The thermogenic effect of thyroid hormone and its clinical implications. Ann Intern Med 139: 205-13.

20. Cannon B, Nedergaard J (2004) Brown adipose tissue: function and physiological significance. Physiol Rev 84: 277-359.

21. Hirsch J, Hudgins LC, Liebel RL, Rosenbaum M (1998) Diet composition and energy balance in humans. Am J Clin Nutr 67: 551S-5S. 
22. MacLean PS, Higgins JA, Johnson GC, Fleming-Elder BK, Donahoo WT, et al. (2004) Enhanced metabolic efficiency contributes to weight regain after weight loss in obesity-prone rats. Am J Physiol Regul Integr Comp Physiol 287: R1306-15.

23. Major GC, Alarie FP, Doré J, Tremblay A (2009) Calcium + vitamin D supplementation and fat mass loss in women very low calcium consumers: potential link with a calcium-specific appetite control. Br J Nutr 101:659-63.

24. Shi H, Norman AW, Okamura WH, Sen A, Zemel MB (2002) 1-25-Dihydroxyvitamin D 3 inhibits uncoupling protein 2 expression in human adipocytes. FASEB J 16: 1808-10.

25. LaKind JS, Goodman M, Nalman DQ (2012) Use of NHANES data to link chemical exposures to chronic diseases: a cautionary tale. PLoS One 7: e51086.

26. Ley RE, Turnbaugh PJ, Klein S, Gordon JI (2006) Human gut microbes associated with obesity. Nature 10.1038/nature4441023a.

27. Westerterp-Plantenga MS, Nieuwenhuizen A, Tomé D, Soenen S, Westerterp KR (2009) Dietary protein, weight loss, and weight maintenance. Annu Rev Nutr 29: 21-41.

28. Murray RK, Granner DK, Mayes PA, Rodwell VW (2003) Harper's Illustrated Biochemistry (26 ${ }^{\text {th }}$ Edn) Mc Graw- Hill, USA.

29. U.S. Department of Agriculture and U.S. Department of Health and Human Services (2015) 2015-2020 Dietary Guidelines for Americans (8 ${ }^{\text {th }}$ Edn), Washington, USA.

30. Garrow JS, James WPT (1993) Human nutrition and dietetics ( $9^{\text {th }}$ Edn) Churchill Livingstone, UK.

31. Lee Y, Hirose H, Ohneda M, Johnson JH, McGarry JD, et al. (1994) Beta-cell lipotoxicity in the pathogenesis of non-insulin-dependent diabetes mellitus of obese rats: impairment in adipocyte-beta-cell relationships. Proc Natl Acad Sci USA 91: 10878-82.

32. Kawahito, S, Kitahata H, Oshita S (2009) Problems associated with glucose toxicity: role of hyperglycemia-induced oxidative stress. World J Gastroenterol 15: 4137-42.

33. Fontana L, Klein S, Holloszy JO (2010) Effects of long-term calorie restriction and Endurance exercise on glucose tolerance, insulin action, and adipokine production. Age (Dordr) 32: 97-108.

34. Saltiel AR (2003) Putting the brakes of insulin signaling. NEJM 349: 2560-62.

35. Melnik B (2012) Leucine signaling in the pathogenesis of type 2 diabetes and obesity. WJDiabetes 3: 38-53.

36. Skeaff CM, Miller J (2009) Dietary Fat and Coronary Heart Disease: Summary of evidence from Prospective Cohort and Randomized Controlled Trials. Ann Nutr Metab 55: 173-201.

37. Spreadbury I (2012) Comparison with ancestral diets suggests dense a celullar carbohydrates promote an inflamatory microbiota, and may be the primary dietary cause of leptin resistance and obesity. Diabetes Metab Syndr Obes 5: 175-189.

38. Mann GV, Spoerry A, Gray M, Jarashow D (1972) Atherosclerosis in the Masai. Am J Epidemiol 95: 26-37.

39. Ho K, Biss K, Mikkelson B, Lewis LA, Taylor CB (1971) The Masai of East Africa: some unique biological characteristics. Arch Pathol 95: $26-37$.

40. Taylor BC, Ho Kang-Jey (1971) Studies on the Masai. Am J Clin Nutr 24: 1291-93.

41. Bang HO, Dyerberg J (1980) Lipid metabolism and ischemic heart disease in Greenland Eskimos. Adv Nutr Res 3:1-22.

42. Prior IA, Davidson F, Salmond CE, Czochanska Z (1981) Cholesterol, coconuts, and diet on Polynesian atolls: a natural experiment: the Pukapuka and Tokelau Island studies. Am J Clin Nutr 34: 1552-61.

43. Estruch R, Martínez-González MA, Corella D, Salas-Salvadó J, Ruiz-Gutiérrez V, et al. (2006) Effects of a Mediterranea-style diet on cardiovascular risk factors: a randomized trial. Ann Intern Med 45: 1-11.

44. Gardner CD, Kiazand A, Alhassan S, Kim S, Stafford RS, et al. (2007) Comparison of the Atkins, Zone, Ornish, and LEARN Diets for Change in Weight and Related Risk Factors among Overweight Premenopausal Women. The A TO Z Weight Loss Study: A Randomized Trial. JAMA 297: $969-77$.

45. Siri-Tarino PW, Sun Q, Hu FB, Krauss RM (2010) Meta-analysis of prospective cohort Studies evaluating the association of saturated fat with cardiovascular disease. Am J Clin Nutr 91: 535-46.

46. Astrup A, Dyerberg J, Elwood P, Hermansen K, Hu FB, et al. (2011) The role of reducing intakes of saturated fat in the prevention of cardiovascular disease: where does the evidence stand in 2010? Am J Clin Nutr 93: 684-8.

47. Jakobsen MU, O’Reilly EJ, Heitmann BL, Pereira MA, Bälter K, et al. (2009) Major types of dietary fat and risk of coronary heart disease: a pooled analysis of 11 cohort studies. Am J Clin Nutr 89: 1425-32.

48. Keys A, Menotti A, Karvonen MJ, Aravanis C, Blackburn H, et al. (1986) The diet and 15-year death rate In the Seven Countries Study. Am J Epidemiol 124: 903-1551.

49. European Cardiovascular Disease Statistics (2005).

50. Mente A, Koning L, Shannon HS, Anand SS (2009) A Systematic Review of the Evidence Supporting a Causal Link between Dietary Factors and Coronary Heart Disease. Arch Int Med 169: 659-69.

51. Skeaff CM, Miller J (2009) Dietary Fat and Coronary Heart Disease: Summary of evidence from Prospective Cohort and Randomised Controlled Trials. Ann Nutr Metab 55: 173-201.

52. Fats and fatty acids in human nutrition (2010) Report of an expert consultation. Geneve. Food and agriculture organization of the United Nations. FAO food and nutrition paper 91. Rome 55: 173-201.

53. Hulbert AJ, Turner N, Storlien LH, Else PL (2005) Dietary fats and membrane function: implications for metabolism and disease. Biol Rev 80: $155-69$.

54. Bonadonna RC, DeFronzo RA (1991) Glucose metabolism in obesity and type II diabetes. Diabete Metab 7: 112-35.

55. Baron AD, Zhu JSH, Weldon H, Maianu L, Garvey WT (1995) Glucosamine induces insulin resistance in vivo by affecting GLUT 4 translocation in skeletal muscle. Implications for glucose toxicity. J Clin Invest 96: 2792-801.

56. Hawkins M, Barzilai N, Liu R, Hu M,Chen W, et al. (1997) Role of the glucosamine pathway in fat-induced insulin resistance. J Clin Invest 99: $2173-82$.

57. Golks A, Guerini D (2008) The O-linked N-acetilglucosamine modification in cellular signalling and the inmune system. EMBO reports 9: 748-53.

58. Obici S, Rossetti L (2003) Minireview: Nutrient Sensing and the Regulation of Insulin Action and Energy Balance. Endocrinology 144: 5172-8.

59. Unger RH (1995) Lipotoxicity in the pathogenesis of obesitydependent NIDDM: genetic and clinical implications. Diabetes 44: 863-70. 
60. Sakai K, Matsumoto K, Nishikawa T, Suefuji M, Nakamaru K, et al. (2003) Mitochondrial reactive oxygen species reduce insulin secretion by pancreatic betacells. Biochem Biophys Res Commun 300: 216-22.

61. Kaneto H, Xu G, Song KH, Suzuma K, Bonner-Weir S, et al. (2001) Activation of the hexosamine pathway leads to deterioration of pancreatic beta-cell function through the induction of oxidative stress. J Biol Chem 276: 31099-104.

62. Kowluru RA (2003) Effect of reinstitution of good glycemic control on retinal oxidative stress and nitrative stress in diabetic rats. Diabetes 52 : 818-23.

63. Prabhakar S, Starnes J, Shi S, Lonis B, Tran R (2007) Diabetic nephropathy is associated with oxidative stress and decreased renal nitric oxide production. J Am Soc Nephrol 18: 2945-52.

64. Brownlee M (2005) The pathobiology of diabetic complications: a unifying mechanism. Diabetes 54: 1615-25.

65. Rossetti L, Giaccari A, DeFronzo RA (1990) Glucose toxicity. Diabetes Care 13: 610-30.

66. Randle PJ, Priestman DA, Mistry SC, Halsall A (1994) Glucose fatty acid interactions and the regulation of glucose disposal. J Cell Biochem 55: 1-11.

67. Perseghin G, Ghosh S, Gerow K, Shulman GI (1997) Metabolic defects in lean non diabetic offspring of NIDDM parents: a cross-sectional study. Diabetes 46: 1001-9.

68. Saloranta C, Groop L (1996) Interactions between glucose and FFA metabolism in man. Diabetes Metab Rev 12: 15-36.

69. Boden G (1997) Role of fatty acids in the pathogenesis of insulin resistance and NIDDM. Diabetes 46: 3-10.

70. Bajaj M, Suraamornkul S, Romanelli A, Cline GW, Mandarino LJ, et al. (2005) Effect of a sustained reduction in plasma free fatty acid concentration on intramuscular long-chain fatty acyl-CoAs and insulin action in type 2 diabetic patients. Diabetes 54: 3148-53.

71. Bajaj M, Suraamornkul S, Kashyap S, Cusi K, Mandarino L, et al. (2004) Sustained reduction in plasma free fatty acid concentration improves insulin action without altering plasma adipocytokine levels in subjects with strong family history of type 2 diabetes. J of Clinical Endocrinology and Metabolism 89: 4649-55.

72. Lands B (2008) A critique of paradoxes in current advice on dietary lipids. Progress in Lipid Research 47: 77-106.

73. Wildman RP, Muntner P, Reynolds K, McGinn AP, Rajpathak S, et al. (2008) The Obese Without Cardiometabolic Risk Factor Clustering and the Normal Weight With Cardiometabolic Risk Factor Clustering : prevalence and correlates of 2 phenotypes among the US population (NHANES 1999-2004). Arch Intern Med 168: 1617-24.

74. Hetherington A, Ranson SW (1940) Hypothalamic lessons in the rat. Anat Rec 78: 1-49.

75. Inohue S, Bray GA, Mullen YS (1998) Transplantation of pancreatic beta-cells prevents the development of hyphotalamic obesity in rats. Am J Physiol 235: E 266.

76. Mehran AE, Templeman NM, Brigidi GS, Lim GE, Chu KY, et al. (2012) Hyperinsulinemia Drives Diet-Induced Obesity Independently of Brain Insulin Production. Cell Metabolism16: 723-37.

77. Cornaro L (1917) The Art of Living Long. A New and Improved English Version of the Treatise by the Celebrated Venetian Centenarian Luigi Cornaro. Bulter. W.F., Milwaukee.

78. Hursting SD, Dunlap SM (2012) Obesity, metabolic dysregulation, and cancer: a growing concern and an inflammatory (and microenvironmental) issue. Ann N Y Acad Sci 1271: 82-7.

79. Godsland IF (2010) Insulin resistance and hyperinsulinaemia in the development and progression of cancer. Clinical Science 118: $315-32$.

80. Yakar S, Leroith D, Brodt P (2005) The role of the growth hormone/insulin-like growth factor axis in tumor growth and progression: lessons from animal models. Cytokine Growth Factor Rev 16: 407-20.

81. Avruch J, Hara K, Lin Y, Liu M, Long X, et al. (2006) Insulin and amino-acid regulation of mTOR signaling and kinase activity through the Rheb GTPase. Oncogene 25: 6361-72.

82. Rollo CD (2010) Aging and the mammalian regulatory triumvirate. Aging Dis 2: 105-38.

83. Paik JK, Kolipara R, Chu G, Ji H, Xiao Y, et al. (2007) FoxOs are lineage-restricted redundant tumor supressors and regulate endothelial cell homeostasis. Cell 128: 309-23.

84. Carter ME, Brunet A (2007) FOXO transcription factors. Current Biology 17: R114.

85. Shaw RJ, Bardeesy N, Manning BD, Lopez L, Kosmatka M, et al. (2004) The LKB1 tumor suppressor negatively regulates mTOR signaling. Cancer Cell 6: 91-9.

86. Corradetti MN, Inoki K, Bardeesy N, DePinho RA, Guan KL (2004) Regulation of the TSC pathway by LKB1: evidence of a molecular link between tuberous sclerosis complex and Peutz-Jeghers syndrome. Genes Dev 18: 1533-8.

87. Shaw RJ, Kosmatka M, Bardeesy N, Hurley RL, Witters LA, et al. (2004) The tumor suppressor LKB1 kinase directly activates AMP-activated kinase and regulates apoptosis in response to energy stress. Proc Natl Acad Sci USA 101: 3329-35.

88. Carrera AC (2004) TOR signaling in mammals. J Cell Sci 117: 4615-6.

89. Saltiel AR, Kahn CR (2001) Insulin signalling and the regulation of glucose and lipid metabolism. Nature 414: 799-806.

90. Virkamaki A, Ueki K, Kahn CR (1999) Protein-protein interaction in insulin signaling and the molecular mechanisms of insulin resistance. J Clin Invest 103 931-43.

91. Abdul-Ghani MA, DeFronzo RA (2010) Pathogenesis of Insulin Resistance in Skeletal Muscle. J of Biomedicine and Biotechnology doi:10.1155/2010/476279.

92. Blagosklonny MV (2011) Rapamycin-induced glucose intolerance: Hunger or starvation diabetes. Cell Cycle 10: 4217-24.

93. Keogh A, Richardson M, Ruygrok P, Spratt P, Galbraith A, et al. (2004) Sirolimus in de novo heart transplant recipients reduces acute rejection and prevents coronary artery disease at 2 years: a randomized clinical trial. Circulation 110: 2694-700.

94. Rodriguez AE, Granada JF, Rodriguez-Alemparte M, Vigo CF, Delgado J, et al. (2006) Oral Rapamycin After Coronary Bare-Metal Stent Implantation to Prevent Restenosis The Prospective, Randomized Oral Rapamycin in Argentina (ORAR II) Study. J Am Coll Cardiol 47: 1522-9.

95. Sarbassov dos D, Ali SM, Sabatini DM (2005) Growing roles for the mTOR pathway. Curr Opin Cell Biol 17: 596-603.

96. Kirkwood TB (2005) Understanding the odd science of aging. Cell 120: 437-47.

97. Blagosklonny MV (2012) Once again on rapamycin-induced insulin resistance and longevity:despite of or owing to. Aging 4: 350-8.

98. Higgins PB, Bastarrachea RA, Lopez-Alvarenga JC, Garcia-Forey M, Proffitt JM, et al. (2010) Eight week exposure to a high sugar high fat diet results in adiposity gain and alterations in metabolic biomarkers in baboons (Papiohamadryassp.). Cardiovasc Diabetol 9: 71. 
99. MacQueen HA, Sadler DA, Moore SA, Daya S, Brown JY, et al. (2007) Deleterious effects of a cafeteria diet on the livers of non-obese rats. Nutr Res 27: 38-47. 100. Aeberli I, Gerber PA, Hochuli M, Kohler S, Haile SR, et al. (2011) Low to moderate sugar-sweetened beverage consumption impairs glucose and lipid metabolism and promotes inflammation in healthy young men: a randomized controlled trial. Am J Clin Nutr 94: 479-85.

101. Browning JD, Szczepaniak LS, Dobbins R, Nuremberg P, Horton JD, et al. (2004) Prevalence of hepatic steatosis in an urban population in the United States: impact of ethnicity. Hepatology 40: 1387-95.

102. Bugianesi E, Leone N, Vanni E, Marchesini G, Brunello F, et al. (2002) Expanding the natural history of nonalcoholic steatohepatitis: from cryptogenic cirrhosis to hepatocellular Carcinoma. Gastroenterology 123: 134-40.

103. Willner IR, Waters B, Patil SR, Reuben A, Morelli J, et al. (2001) Ninety patients with nonalcoholic steatohepatitis: insulin resistance, familial tendency, and severity of disease. Am J Gastroenterol 96: 2957-61.

104. Angulo P (2002) Nonalcoholic fatty liver disease. N Engl J Med 346: 1221-31.

105. Putnam JJ, Allshouse JE (1999) Food consumption, prices and expenditures, 1970-97. US Department of Agriculture Economic Research Service statistical bulletin no. 965, April 1999. Washington, DC: US Government Printing Office.

106. Vos MB, Kimmons JE, Gillespie C, Welsh J, Blanck HM (2008) Dietary fructose consumption among US children and adults: The Third National Health and Nutrition Examination Survey. Medscape J Med 10: 160.

107. Ervin RB, Ogden CL (2013) Consumption of Added Sugars among U.S. Adults, 2005-2010. NCHS Data Brief 122: 1-8.

108. Casella N (2010) Carrasco Manrique AL, Mesa Milton A. Presencia de jarabe de maiz de alta fructosa en snacks. Actualización en nutrición 11: 185-93.

109. Petersen KF, Laurent D, Yu C, Cline GW, Shulman GI (2001) Stimulating effects of low-dose fructose on insulin-stimulated hepatic glycogen synthesis in humans. Diabetes 50: 1263-8.

110. Mayes PA (1993) Intermediary metabolism of fructose. Am J Clin Nutr 58: 754S-65S.

111. Bantle JP, Laine DC, Castle GW, Thomas JW, Hoogwerf BJ, et al. (1983) Postprandial glucose and insulin responses to meals containing different carbohydrates in normal and diabetic subjects. N Engl J Med 309: 7-12.

112. Havel PJ (1997) Glucose but not fructose infusion increases circulating leptin in proportion to adipose stores in rhesus monkeys. Diabetes 105: 37-8.

113. Ouyang X, Cirillo P, Sautin Y, McCall S, Bruchette JL, et al. (2008) Fructose Consumption as a Risk Factor for Non-alcoholic Fatty Liver Disease. J Hepatol 48: 993-9.

114. Hofmann SM, Tschop MH (2009) Dietary sugars: a fat difference. JCI 119: 1089-92.

115. Taylor EN, Curhan GC (2008) Fructose consumption and the risk of kidney stones. Kidney Int 73: 489-96.

116. Choi HK, Curhan G (2008) Soft drinks, fructose consumption, and the risk of gout in men: prospective cohort study. BMJ 336: $309-12$.

117. Johnson RJ, Perez-Pozo SE, Sautin YY, Manitius J, Sanchez-Lozada LG, et al. (2009) Hypothesis: Could excessive fructose intake and uric acid cause type 2 diabetes? Endocr Rev 30: 96-116.

118. Nakagawa T, Tuttle KR, Short R, Johnson RJ (2006) Hypothesis: Fructose induced hyperuricemia as a causal mechanism for the epidemic of the metabolic syndrome. Nat Clin Pract Nephrol 1: 80-6.

119. Kanellis J, Kang DH (2005) Uric acid as a mediator of endothelial dysfunction, inflammation, and vascular disease. Semin Nephrol 25: 39-42.

120. Alderman MH, Cohen H, Madhavan S, Kivlighn S (1999) Serum Uric Acid and Cardiovascular Events in Successfully Treated Hypertensive patients. Hypertension 34: 144-50.

121. Bergheim I, Weber S, Vos M, Kramer S, Volynets V, et al. (2008) Antibiotics protect against fructose induced hepatic lipid accumulation in mice: role of endotoxin. J Hepatology 48: 983-92.

122. Lustig RH (2013) Fructose: It's“Alcohol without the Buzz". Adv Nutr 4: 226-35.

123. Aarsland A, Chinkes D, Wolfe RR (1996) Contributions of de novo synthesis of fatty acids to total VLDL-triglyceride secretion during prolonged hyperglycemia/ hyperinsulinemia in normal man. J Clin Invest 98: 2008-17.

124. Stanhope KL, Schwarz JM, Keim NL, Griffen SC, Bremer AA, et al. (2009) Consuming fructose sweetened, not glucose-sweetened, beverages increases visceral adiposity and lipids and decreases insulin sensitivity in overweight/obese humans. J Clin Invest 119: 1322-34.

125. Cave M, Deaciuc I, Mendez C, Song Z, Joshi-Barve S, et al. (2007) Nonalcoholic fatty liver disease: Predisposing factors and the role of nutrition. J Nutr Biochem 18: 184-95.

126. Zivkovic AM, German JB, Sanyal AJ (2007) Comparative review of diets for the metabolic syndrome: Implications for nonalcoholic fatty liver disease. Am J Clin Nutr 86: 285-300.

127. Jurgens H, Haass W, Castaneda TR, Schurmann A, Koebnick C, et al. (2005) Consuming fructose-sweetened beverages increases body adiposity in mice. Obes Res 13: 1146-56.

128. Ackerman Z, Oron-Herman M, Grozovski M, Rosenthal T, Pappo O, et al. (2005) Fructose-induced fatty liver disease: Hepatic effects of blood pressure and plasma triglyceride reduction.Hypertension 45: 1012-8.

129. Schwarz JM, Noworolski SM, Lee GA, Wen M, Dyachenko A, et al. (2009) Effects of short-term feeding with high- vs low- fructose isoenergetic diets on hepatic de novo lipogenesis, liver fat content and glucose regulation. Diabetes 1476P.

130. Sacks FM, Bray GA, Carey VJ, Smith SR, Ryan DH, et al. (2009) Comparison of Weight-Loss Diets with Different Compositions of Fat, Protein, and Carbohydrates NEJM 360: 859-73. 


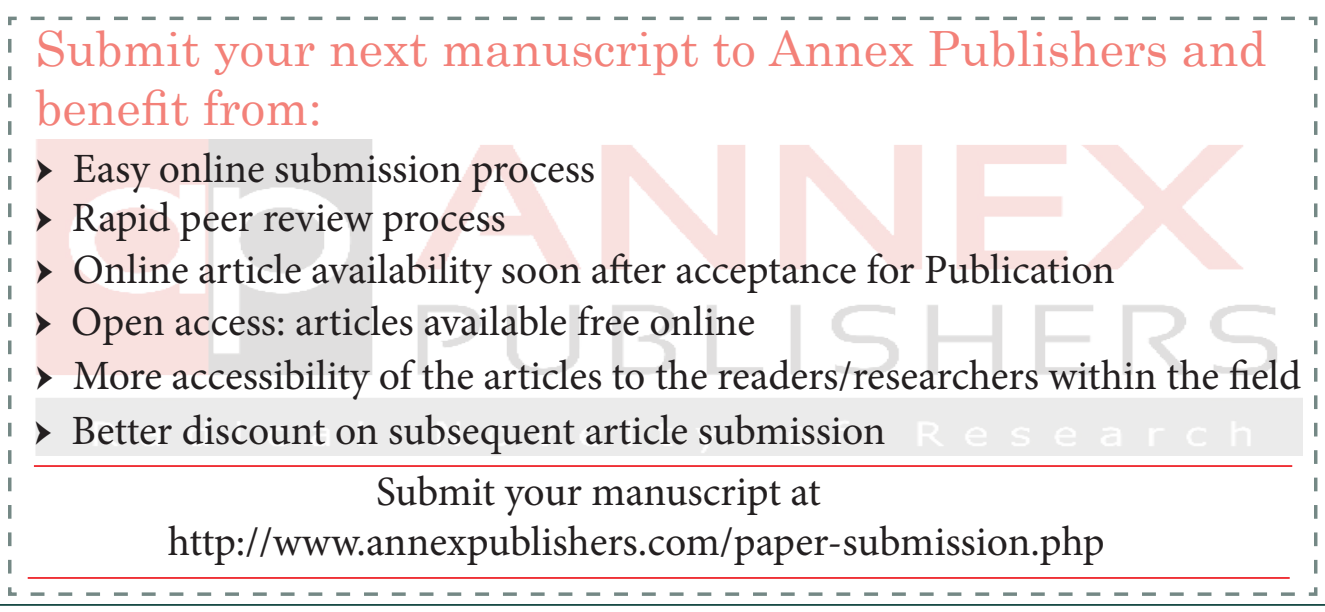

